\title{
(5)

\section{En kvinne i 40-årene som brukte vanedannende legemidler i svært høye doser}

NOE $\AA$ LAERE AV

\section{ANNE TARALDSEN HELDAL}

E-post: anne.taraldsen.heldal@sshf.no

Avdeling for rus- og avhengighetsbehandling

Sørlandet sykehus

Anne Taraldsen Heldal er ph.d. og lege i spesialisering i rus- og avhengighetsmedisin.

Forfatteren har fylt ut ICMJE-skjemaet og oppgir ingen interessekonflikter.

\section{TROND OSKAR AAMO}

Avdeling for klinisk farmakologi

St. Olavs hospital

Trond Oskar Aamo er spesialist i klinisk farmakologi og avdelingssjef.

Forfatteren har fylt ut ICMJE-skjemaet og oppgir ingen interessekonflikter.

\section{JOACHIM FROST}

Avdeling for klinisk farmakologi

St. Olavs hospital

og

Institutt for klinisk og molekylær medisin

NTNU

Joachim Frost er ph.d., spesialist i klinisk farmakologi, overlege og førsteamanuensis.

Forfatteren har fylt ut ICMJE-skjemaet og oppgir ingen interessekonflikter.

En kvinne i 4o-årene fikk forskrevet opioider i forbindelse med et operativt inngrep. Forskrivningen eskalerte i etterkant til enorme doser som viste seg å skape utfordringer i det videre behandlingsforløpet.

En kvinne i 40-årene hadde i forbindelse med et operativt inngrep startet med opioidet oksykodon. Hun var ellers tidligere stort sett frisk, hadde ingen kjent rushistorikk og var i full jobb. Etter utskrivelsen hadde hun fortsatt med opioidbehandlingen med videre forskrivning fra fastlege. Forskrivningen eskalerte over noen år, og første gang rusbehandlingsinstitusjon ble kontaktet, stod pasienten på totalt 11 ooo mg oksykodon per døgn (2 ooo mg OxyNorm korttidsvirkende kapsler og 9 ooo mg OxyContin depottabletter). Pasienten fortalte at hun inntok oksykodon omtrent 15 ganger gjennom døgnet. I tillegg fikk hun forskrevet benzodiazepinet oksazepam(Sobril) i en dose på 500 mg per døgn (figur 1 ). 


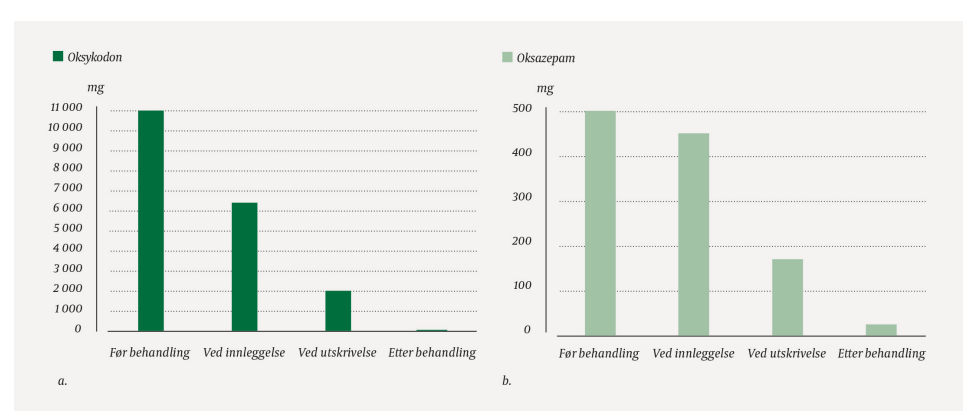

Figur 1 Pasientens døgndoser av a) oksykodon og b) oksazepam underveis i behandlingsforløpet.

Oksykodon er et semisyntetisk opioid og utøver sin analgetiske effekt som en ren opioidagonist uten antagonistisk effekt, hovedsakelig via $\mu$-opioidreseptorer. Godkjent indikasjon er sterke opioidfølsomme smerter, slik som smerter ved kreft. Oksykodon omdannes via enzymene $\mathrm{CYP}_{3} \mathrm{~A}_{4}$ og $\mathrm{CYP}_{2} \mathrm{D} 6$ til hovedsakelig inaktive metabolitter. Halveringstiden er kort, i gjennomsnitt tre timer ved bruk av kortidsvirkende formuleringer og fire-seks timer ved bruk av depotformuleringer (1). For depottabletter er det vanlig med startdose for ikke-tilvendte pasienter på 10-20 mg hver tolvte time. For kapsler og tabletter er vanlig startdose $5 \mathrm{mg}$ hver sjette time. Ved peroral bruk tilsvarer $10 \mathrm{mg}$ oksykodon omtrent $15 \mathrm{mg}$ morfin (2).

Toleranseutvikling og fysisk avhengighet er forventede og til dels uunngåelige konsekvenser av langvarig opioidbehandling. Signifikant fysisk avhengighet vil kunne etableres i løpet av to-fire uker med daglig bruk, og abstinens ved brå behandlingsslutt kan oppstå allerede etter et par uker med daglig bruk. Toleranseutviklingen kan bli svært uttalt, noe denne kasuistikken illustrerer.

Ved de første kontaktene mellom pasientens fastlege og rusbehandlingsinstitusjon ble det vurdert som uforsvarlig å legge inn pasienten elektivt for avrusning på grunn av manglende intensiv- og overvåkningsutstyr ved posten. Det var ingen som kunne bekrefte det angitte medikamentinntaket, og det kunne ikke utelukkes at hun drev med videresalg på det illegale markedet selv om det ikke var mistanke om det. Det ble anbefalt innleggelse ved en medisinsk sykehusavdeling slik at overvåkingsutstyr og intensivbehandling var tilgjengelig ved de første observerte inntakene. Dette ble ikke imøtekommet ved henvisning til aktuelle lokalsykehus. I en periode over noen måneder fikk pasienten medisiner av hjemmesykepleie uten observerte inntak. I denne perioden trappet hun ned oksykodoninntaket med $10 \%$ annenhver uke.

Pasienten ble deretter innlagt ved rusbehandlingsinstitusjon. Ved innkomst hadde hun en døgndose på 4920 mg OxyContin og $1480 \mathrm{mg}$ OxyNorm. I tillegg inntok hun ca. $450 \mathrm{mg}$ oksazepam per døgn. Ved innleggelse fortalte hun at hun hadde fått både psykiske og fysiske plager knyttet til det svært høye forbruket. Hun følte seg trøtt, var obstipert og hadde en uttalt følelse av uro. I tillegg hadde hun utviklet betydelige ødemer bilateralt i underekstremitetene, noe hun selv relaterte til oksykodoninntaket. Pasienten hadde hittil stort sett vært i jobb, men hadde etter hvert fungert dårlig både på jobb og sosialt. Hennes ektemann fortalte at hun ofte sovnet på ettermiddagene og kveldene.

Ved innleggelse ble kvinnen vurdert som relativt klinisk upåfallende utover at hun hadde noe problemer med å holde øynene åpne under lengre samtaler. Vitale parametre var blodtrykk $146 / 87 \mathrm{~mm} \mathrm{Hg}$, puls $86 \mathrm{slag} / \mathrm{min}$, respirasjonsfrekvens 14 pust/min, $\mathrm{O}_{2}$-metning $94 \%$, temperatur $36,0^{\circ} \mathrm{C}$ og kroppsmasseindeks $27,2 \mathrm{~kg} / \mathrm{m}^{2}$. Blodprøver var normale bortsett fra forhøyet s-GT på $128 \mathrm{U} / \mathrm{l}$ (referanseområde 10-75 U/l). Kort etter innkomstsamtale med lege fikk pasienten uttalt svette, frysninger og følelse av indre uro. Det var på dette tidspunktet gått omtrent én time over hennes vanlige doseringsintervall for oksykodon, og hun satte selv disse symptomene i forbindelse med det forlengede intervallet.

Hos personer som forskrives vanedannende legemidler (f.eks. opioider, benzodiazepiner og sentralstimulerende medikamenter), kan det være behov for å undersøke om det er et rimelig samsvar mellom målt serumkonsentrasjon og forskrevet dose. Eventuelle avvikende 
svar kan være en indikasjon på høyere eller lavere inntak enn forskrevet, avvikende metabolisme eller videresalg. Det kan også være nyttig ved hjelp av rusmiddeltesting i urin å kontrollere at vedkommende ikke bruker andre lege- eller rusmidler ved siden av det forskrevne legemidlet.

I behandlingsforløpet ble det rekvirert serumkonsentrasjonsmåling av oksykodon og screening av andre opioider i urin ved en klinisk farmakologisk sykehusavdeling. Serumkonsentrasjonen av oksykodon ved første prøvetaking var $2418 \mathrm{nmol} / \mathrm{l}$. Dette er en betydelig høyere konsentrasjon enn man vanligvis måler i serum ved terapeutisk bruk av oksykodon og vil medføre en potensielt dødelig sentraldempende og respirasjonshemmende effekt hos et individ som ikke er tilvent opioider. Til sammenligning har pasienter som bruker døgndoser på inntil 6o mg oksykodon peroralt vanligvis serumkonsentrasjoner under $200 \mathrm{nmol} / \mathrm{l}$ når prøven tas medikamentfastende, og rene oksykodon-dødsfall er rapportert ned til $317 \mathrm{nmol} / \mathrm{l}$. Den målte serumkonsentrasjonen på $2418 \mathrm{nmol} / \mathrm{l}$ var imidlertid lavere enn forventet ut fra den daværende dosen, og kan kanskje være noe av forklaringen på den høye doseringen. Konsentrasjonen kan skyldes inntak av lavere doser enn oppgitt og/eller biologisk variasjon i metabolismen, for eksempel knyttet til økt kapasitet i CYP3A4- eller CYP2D6-systemet. Dette ble imidlertid ikke undersøkt nærmere. Urinscreening for andre opioider var negativ.

I dette tilfellet ble klinisk farmakologisk sykehusavdeling kontaktet et stykke ut i forløpet, og det ble ikke gjort noen systematisk undersøkelse av serumkonsentrasjoner og eventuelt sidemisbruk. Av den grunn mistet man muligheten til å foreta en gjentatt og kontrollert kartlegging av serumkonsentrasjoner i forhold til dosering og evaluering av pasientens utskillelseshastighet under nedtrappingen. Dette kunne med fordel vært gjort, da det kunne ha gitt nyttig informasjon både om pasientens individuelle farmakokinetikk og oksykodons farmakokinetikk ved svært høy dosering i alminnelighet. Slike målinger kunne også ha vært brukt aktivt i vurderingen og planleggingen av nedtrappingen videre. Man kunne da ha supplert med CYP2D6- og CYP3A4-genotyping og sett resultatet av dette i sammenheng med serumkonsentrasjonene. Ettersom det ble foretatt kun få og sporadiske målinger hos denne pasienten, ble nytteverdien av genotyping ikke ansett som stor nok til at man valgte å utføre dette.

Det ble konkludert med at det var sannsynlig at pasienten inntok de oppgitte dosene selv om det manglet sikre observasjoner. Ektemannen bekreftet pasientens opplysninger, og de benektet videresalg. Det ble følgelig besluttet å gi pasienten en enkeltdose på $820 \mathrm{mg}$ OxyContin depottabletter med tett oppfølging av hennes vitalparametre. Forut for dette ble medisinsk sykehusavdeling varslet, og nalokson-antidot ble gjort klar. Doseregimet hun hadde hatt hjemme for oksykodon og oksazepam, ble fulgt de første dagene. Pasienten virket klinisk upåfallende etter inntak av dosene. Etter noen dager med observasjon og medikamentinntak under påsyn ble det lagt en nedtrappingsplan. Målsettingen var nedtrapping på 10-15\% hver femte dag og nedgang til tre-fire faste doser per døgn mens hun var inneliggende. Tidlig i forløpet ønsket man også å konvertere all korttidsvirkende opioidbehandling til depottabletter for å sikre en jevnere serumkonsentrasjon.

Denne nedtrappingen forløp ukomplisert. Pasienten hadde stabile vitalparametre gjennom hele oppholdet. Det ble observert få objektive abstinenssymptomer basert på Clinical Opiate Withdrawal Scale (COWS), men pasienten beskrev mye uro siste timen før neste dose. Pasienten sov omtrent fire-fem timer per natt. Hun fikk tett oppfølging gjennom døgnet med psykososial støtte og miljøterapi. Under oppholdet på til sammen seks uker ble hun mer våken, mindre plaget med uro og i stand til å føre lengre samtaler uten å falle ut eller sovne. Pasienten ga lite uttrykk for økende smerter gjennom oppholdet. Ved utskrivelse stod hun på $2000 \mathrm{mg}$ oksykodon depotpreparat og $170 \mathrm{mg}$ oksazepam per døgn. Det ble lagt en videre nedtrappingsplan på $10 \%$ hver uke for oksykodon og $10 \%$ annenhver uke for oksazepam over seks måneder. Man fokuserte på at hun kunne utsette en nedtrapping, men ikke øke doseringen. Det ble planlagt ny elektiv innleggelse midtveis i denne planen for å kontrollere og eventuelt justere nedtrappingen. Pasienten ble henvist til 
poliklinisk oppfølging for støttebehandling i den videre nedtrappingen. Vi ønsket også at man forsøkte å finne ikke-medikamentelle måter å håndtere smertene hennes på i det polikliniske behandlingstilbudet.

I Nasjonal faglig retningslinje for avrusning fra rusmidler og vanedannende legemidler er det under beskrivelsen av avrusning fra opioider anbefalt at buprenorfin (primært med nalokson) skal være førstevalg både i og utenfor legemiddelassistert rehabilitering, mens metadon ikke anbefales ved polikliniske avrusninger (3). Forskningsgrunnlaget for å anbefale rutinemessig konvertering til buprenorfin eller metadon ved avrusning og nedtrapping av andre opioider er imidlertid begrenset.

Buprenorfin er en partiell $\mu$-opioidreseptoragonist/-antagonist. Hvis buprenorfin inntas etter inntak av rene agonister, kan disse fortrenges fra opioidreseptorene på grunn av ulikheter i reseptoraffinitet $(4,5)$. Hos vår pasient ble det derfor vurdert som for risikabelt å skifte til buprenorfin.

Det ble videre vurdert overgang til metadon etter «stop and go»-prinsippet (6) ettersom metadon er en ren $\mu$-opioidreseptoragonist. Det forelå imidlertid ingen konverteringstabeller eller anbefalinger for så høye doser som i dette tilfellet. Fordi man hadde lite å støtte seg på i litteraturen når det gjaldt konvertering til metadon, ble det besluttet å trappe ned doseringen på det opioidet hun var tilvent. Hovedprinsippet vi brukte, var å gi alt oksykodon som depotformulering og i så få doseringer som mulig.

To måneder etter utskrivelse kom pasienten inn for et nytt opphold fordi hun i institusjon kunne trappe ned raskere enn det man anså tilrådelig å gjøre poliklinisk. Ved denne innleggelsen fortalte pasienten at hun hadde fulgt nedtrappingsplanen konsekvent for oksykodon, men at hun hadde utsatt noen nedtrappinger av oksazepam. Under dette oppholdet, som varte i ti dager, ble nedtrappingsfrekvensen $\emptyset$ kt til hver tredje dag. Det ble sammen med pasienten lagt en justert nedtrappingsplan med planlagt seponering av oksykodon om fem måneder og oksazepam om fire måneder. Hun ønsket selv å trappe ned begge medikamentene parallelt. Ved neste kontakt brukte hun $50 \mathrm{mg}$ oksykodon og $25 \mathrm{mg}$ oksazepam per døgn og ønsket ikke videre nedtrapping før hun hadde gjennomført et planlagt kirurgisk inngrep.

\section{Diskusjon}

Så vidt vi kjenner til, finnes det ingen detaljerte beskrivelser i faglitteraturen av pasienter som har inntatt så store doser opioider som denne pasienten. I vår kliniske praksis har vi heller ikke håndtert pasienter med slike ekstreme døgndoser tidligere. Det var derfor en stor utfordring å behandle en slik pasient i en avrusningsenhet. Studier har vist at risikoen for overdose øker med høy total dose over tid (7), og det var viktig at man tidligst mulig fikk klarhet i de faktiske døgndosene. Avrusningsenheten denne pasienten var innlagt på, var dårlig rustet til å håndtere eventuelle akuttmedisinske komplikasjoner, spesielt med tanke på overvåking og understøttende behandling av våkenhet og respirasjon. På den annen side var det heller ingen andre rusinstitusjoner i regionen som hadde mer kompetanse eller ressurser til å håndtere slik nedtrapping på en forsvarlig måte.

Vår pasient fikk også forskrevet en betydelig dose av benzodiazepinet oksazepam. I Nasjonal faglig veileder for vanedannende legemidler er det en tydelig anbefaling om ikke å forskrive benzodiazepiner til pasienter som får forskrevet opioider mot kroniske ikke-kreftrelaterte smerter, fordi kombinasjonen kan forsterke stoffenes dempende effekter på sentralnervesystemet med respirasjonsdepresjon og død som ytterste konsekvens (8).

Den amerikanske epidemien med misbruk og overdoser av opioider er sett på som en av de største helsekrisene i USA i moderne tid $(9,10)$. Situasjonen i landet er trolig tett sammenvevd med måten det amerikanske helsevesenet er organisert på, ikke minst det spillerommet som gis til den farmasøytiske industrien. Selv om man per i dag ikke har lignende tilstander i Norge, illustrerer denne kasuistikken at det likevel er risiko for at pasienter kan rammes av avhengighet og skade knyttet til feil bruk av opioider her til lands. 
Tall fra det norske reseptregisteret i perioden 2004-17 viser at forskrivningen av oksykodon i Norge er $\emptyset$ kende. I en studie fra 2014 der man så på trenden av forskrivning av sterke opioider, fant man økende bruk i aldersgruppen 41-8o år, spesielt for oksykodon og buprenorfin (11).

Årsakene til at vår pasient havnet i denne situasjonen, er uklare, men det er flere aspekter man kan peke på. Pasienten ble satt på oksykodon i forbindelse med en ikke-kreftrelatert smertetilstand av spesialisthelsetjenesten. I oppstarten ble det ikke diskutert noen nedtrappingsplan eller annen ramme for forskrivningen. Det kan også ha spilt en rolle at det var et skifte av fastlege i denne perioden. Pasienten var en ressurssterk person uten tidligere rushistorikk. Det kan derfor i mindre grad ha blitt satt spørsmålstegn ved de stadige henvendelsene om ny forskrivning. Apotekinnehaver sendte ifølge pasienten imidlertid flere bekymringsmeldinger til fastlege. Pasienten ble også henvist til et lokalsykehus og et distriktspsykiatrisk senter uten at disse institusjonene oppfattet omfanget av pasientens problem. Til slutt var det Helseøkonomiforvaltningen (Helfo) som ikke lenger ville dekke utgiftene knyttet til legemiddelbruken, noe som førte til at pasienten fikk store økonomiske utlegg. Dette ble også foranledningen til at pasienten selv gikk til fastlegen med ønske om å trappe ned. Legemiddelmyndighetene har på sin side bidratt til å senke terskelen for forskrivning av sterke opioider ved langvarige ikkekreftrelaterte smerter etter innføringen av refusjonskode -71 i 2008, en «samlediagnose» som åpner for individuell refusjon av opioider for en stor og vagt definert gruppe smertepasienter (12). Bruken av denne refusjonskoden ble ytterligere liberalisert i 2016, da fastleger også ble gitt anledning til å søke om refusjon for døgndoser opp til 100 mg orale morfinekvivalenter under visse vilkår. Fastlegene har en viktig rolle som portvoktere i forskrivningen av vanedannende legemidler. Likevel er det slik at alle instanser og alt helsepersonell som er involvert i behandling av pasienter som forskrives opioider, spesielt ved langvarige ikke-kreftrelaterte smerter, har et ansvar og skal være årvåkne for slik medisinering. I denne pasienthistorien er det åpenbart at flere instanser har sviktet. De menneskelige kostnadene ved en slik forskrivning kan være fatale og får ringvirkninger for både pasienten, pårørende og samfunnet.

Kasuistikken viser at det er mulig å gjennomføre en nedtrapping også ved så store døgndoser når man bruker tilstrekkelig tid og etablerer en god allianse med pasienten. Det er likevel nødvendig å diskutere nærmere behovet for et samarbeid mellom rus- og avhengighetsmedisinske, medisinske og klinisk farmakologiske avdelinger i slike saker, der ingen av sykehusavdelingene besitter den nødvendige kompetansen alene.

\section{LITTERATUR:}

1. Lugo RA, Kern SE. The pharmacokinetics of oxycodone. J Pain Palliat Care Pharmacother 2004; 18: 17-30. [PubMed][CrossRef]

2. Norsk legemiddelhåndbok. Oslo: Foreningen for utgivelse av Norsk legemiddelhåndbok, 2013.

3. Nasjonal faglig retningslinje for avrusning fra rusmidler og vanedannende legemidler. Avrusning fra opioider. Oslo: Helsedirektoratet, 2016.

https://www.helsedirektoratet.no/retningslinjer/avrusning-fra-rusmidler-og-vanedannende-legemidle r/avrusning-fra-opioider Lest 17.9.2019.

4. Rosenthal RN, Goradia VV. Advances in the delivery of buprenorphine for opioid dependence. Drug Des Devel Ther 2017; 11: 2493-505. [PubMed][CrossRef]

5. Bramness JG, Bachs LC, Waal H. Buprenorfin i legemiddelassistert rehabilitering av heroinavhengige. Tidsskr Nor Lægeforen 2002; 122: 2452-4. [PubMed]

6. Moksnes K, Dale O, Rosland JH et al. How to switch from morphine or oxycodone to methadone in cancer patients? a randomised clinical phase II trial. Eur J Cancer 2011; 47: 2463-70.

[PubMed][CrossRef]

7. Liang Y, Turner BJ. Assessing risk for drug overdose in a national cohort: role for both daily and total 
opioid dose? J Pain 2015; 16: 318-25. [PubMed][CrossRef]

8. Nasjonal faglig veileder vanedannende legemidler. Utfordrende situasjoner og tilstander ved rekvirering av vanedannende legemidler. Oslo: Helsedirektoratet, 2015.

https://www.helsedirektoratet.no/veiledere/vanedannende-legemidler Lest 17.9.2019.

9. Rudd RA, Seth P, David F et al. Increases in drug and opioid-involved overdose deaths - United States, 2010-2015. MMWR Morb Mortal Wkly Rep 2016; 65: 1445-52. [PubMed][CrossRef]

10. Schuchat A, Houry D, Guy GP. New data on opioid use and prescribing in the United States. JAMA 2017; 318: 425-6. [PubMed][CrossRef]

11. Neutel CI, Skurtveit S, Berg C et al. Trends in prescription of strong opioids for 41-8o year old Norwegians, 2005-2010. Eur ] Pain 2014; 18: 438-46. [PubMed][CrossRef]

12. Persheim MS, Helland $\mathrm{A}$, Spigset $\mathrm{O}$ et al. Potensielt vanedannende legemidler på blåresept ved kroniske sterke smerter. Tidsskr Nor Legeforen 2013; 133: 150-4. [PubMed][CrossRef]

Publisert: 2. januar 2020. Tidsskr Nor Legeforen. DOI: 10.4045/tidsskr.19.0287

Mottatt 5.4.2019, første revisjon innsendt 7.8.2019, godkjent 17.9.2019.

(C) Tidsskrift for Den norske legeforening 2020. Lastet ned fra tidsskriftet.no 